\title{
The Contribution of Self-Control towards Student Smartphone Addiction
}

\author{
Rizki Adiyatma $\left.{ }^{1}, \mathrm{Mudjiran}^{2}, \mathrm{Afdal}^{3^{*}}\right)$ \\ ${ }^{123}$ Universitas Negeri Padang \\ *) Correspondence Author, e-mail: afdal@konselor.org
}

\begin{abstract}
The presence of smartphones has caused major changes in human life, including among students. This causes the problem of smartphone addiction in students which causes their daily life to be disrupted. This study aims to reveal the contribution of selfcontrol towards student smartphone addiction. This study was descriptive quantitative, and the data were analyzed by using a simple linear regression. The population in this study was 33480 students of undergraduate program at Universitas Negeri Padang in 2015-2019 academic year. The sample of this study was 400 students taken by using the Proportional Random Sampling technique. The research instrument used was the selfcontrol and smartphone addiction scale with a Likert scale model. The research findings revealed that self-control gives an effective contribution towards the student smartphone addiction at Univeristas Negeri Padang as many as $30.1 \%$.
\end{abstract}

Keywords: Self-Control, Smartphone Addiction.

Article History: Received on 13/07/2020; Revised on 30/07/2020; Accepted on 15/08/2020; Published Online: 10/09/2020.

(c) (i) This is an open access article distributed under the Creative Commons Attribution License, which permits unrestricted use, distribution, and reproduction in any medium, provided the original work is properly cited. (C2020 by author.

\section{INTRODUCTION}

Smartphones are sophisticated communication tools that combine functionality and personal computers consisting of text messages, cameras, music players, videos, games, email access, digital television, search engines, personal information managers, Global Positioning System (GPS) features and internet access (Hanika, 2015; Williams \& Sawyer, 2011; Youarti \& Hidayah, 2018). Moreover, Waizly (2012) states that smartphones are generally used as a means of communication, playing games and accessing the internet, such as opening social media, searching for information to shopping online. This is supported by the highest number of smartphone users who are adolescents in the age group 16 to 21 years, where these adolescents belong to the $\mathrm{Z}$ generation category, which is individuals who were born in the period 1995-2010 when technological developments developed rapidly (Manap et al., 2016; Putra, 2017). The advantages of these smartphones make individuals experience a tendency to use them continuously, causing forgetfulness of their surroundings and the emergence of indifference to the environment which is 
called antisocial behavior and makes individuals addicted (Bian \& Leung, 2014; Dewanti, Widada \& Triyono, 2016).

Obviously, smartphone addiction is the behavior of an individual's attachment or dependence on internet-based smartphones and using them for hours can cause social problems and difficulties in living everyday life due to poor self-control disorders (Griffiths, 2015; Kwon et al, 2013; Young \& Cristiano, 2011). Then, smartphone addiction can have a negative impact on individuals such as a lack of concern for the surrounding environment so that individuals tend to have individualistic and egocentric attitudes, not being able to manage time when using a smartphone and can affect health and sleep quality (Demirci, Akgonul \& Akpinar, 2015; Nasution, Neviyarni \& Alizamar, 2017). Smartphone addiction also has an impact on psychological symptoms such as depression, anxiety disorders, mood disorders, personality disorders and can cause Nomo phobic behavior, namely the fear experienced by individuals because they are far from smartphones (Lepp, Barkley \& Karpinski, 2013; King et al, 2014).

A study conducted by Putra, Ifdil \& Afdal (2019) in the Guidance and Counseling Department, Faculty of Education, Universitas Negeri Padang, revealed the phenomenon of students who have smartphone addiction that there were students who ignore others because they are busy opening social media and online games, talking to himself, laughing to himself when looking at the smartphone and sitting around the corners of the campus building. In addition, the students can be said to have a dependency on smartphones by looking at the frequency of smartphone use throughout the day, so this dependence in the end leads to an antisocial attitude among students (Yusnita \& Syam, 2017).

Smartphone addiction of students can be affected by many factors. One of the factors is student self-control (Rachdianti, 2011; Rambe, Mudjiran \& Marjohan, 2017). Students with high self-control should be able to avoid various negative behaviors, so they can resist the urge or desire to behave that is not in accordance with social norms (Chapple, 2005; Khairunnisa, 2013; Thalib, 2010). Meanwhile, students with a low level of self-control tend to have difficulties in changing the situation, so it causes anxiety in themselves and this anxiety makes them difficult to focus, lack of enthusiasm, and act arbitrarily (Sofyan, 2010; De vito, 1995; Averill, 1973).

Smartphone addiction can disrupt students' daily lives and have an impact on poor health and affect their social relationships (Yuwanto, 2010). Based on the explanation above, it can be said that smartphone addiction of students is inseparable from the level of their self-control. Therefore, the role of counselors is really needed to improve the students' self-control in reducing smartphone addiction. This study can be used as a reference or need assessment and can help counselors to improve their quality and performance, especially as an input for developing guidance and counseling programs. To reduce the level of student smartphone addiction, counselors need to improve the students' self-control through various guidance and counseling services such as group guiding, group counseling, individual counseling, and information services. 


\section{METHOD}

This study used simple linear regression analysis technique. The population in this study was 33480 students of undergraduate program at Universitas Negeri Padang classified as generation Z, namely individuals who were born started from 1995 to 2010. The, the sample in this study was 400 students taken from each faculty, taken by using the Proportional Random Sampling technique. The use of this technique is because the number of each population is not homogeneous, this technique is also carried out so that the number of samples in each stratum is proportional to the number of the members of the population. The instrument used in this study was the self-control and smartphone addiction scale with a Likert model which has been tested for validity and reliability first. The research data were analyzed through a simple linear regression technique, due to identifying the contribution of the self-control variable $(X)$ to the smartphone addiction variable $(\mathrm{Y})$.

\section{RESULTS AND DISCUSSION}

The data of this study consisted of self-control variable $(X)$ and smartphone addiction variable $(Y)$. The following are the results of the data analysis obtained.

Table 1. The Results Of Simple Linear Regression Test On Self-Control (X) Towards Smartphone Addiction (Y)

\begin{tabular}{cccc}
\hline Variabel & $\boldsymbol{R}$ & $\begin{array}{c}\boldsymbol{R} \\
\text { Square }\end{array}$ & $\begin{array}{c}\text { Adjusted } \boldsymbol{R} \\
\text { Square }\end{array}$ \\
\hline $\mathrm{X}-\mathrm{Y}$ & 0,548 & 0,301 & 0,299 \\
\hline
\end{tabular}

Table 1. shows that the correlation value (R) obtained was 0.548, with an $R$ Square value 0.301, while the adjusted regression coefficient (Adjusted $R$ Square) was 0.299. This proved that self-control has a significant contribution to smartphone addiction with an effective contribution that was $30.1 \%$, while the remaining was $69.9 \%$ affected by other factors. It means that to reduce the level of smartphone addiction it can be done through improving the students' self-control. Based on these findings, self-control contributes significantly and has a negative correlation to student smartphone addiction, where the higher the self-control, the lower the level of smartphone addiction and conversely the lower the self-control, the higher the level of smartphone addiction. The results of this study are basically in line with the findings of a study conducted by Asih \& Fauziah (2017) which stated that self-control has a negative effect and relationship on student smartphone addiction.

Thus, it can be concluded that the lower the level of self-control they have is the higher the level of student smartphone addiction. Then, the higher the level of their self-control is the lower the level of their smartphone addiction. This is because the ability of the students to control themselves in using smartphones excessively (Agusta, 2016; Chiu, 2014; Jiang \& Zhao, 2016; Rachdianti, 2011). These findings proved that self-control has an important role in controlling the use of smartphones in a healthy and appropriate manner, 
so that they are not excessive and avoid smartphone addiction behavior (Karuniawan \& Cahyanti, 2013; Wan \& Chiou, 2006; Widiana, Retnowati, \& Hidayat, 2004).

\section{CONCLUSIONS}

Based on the results of this study, it can be concluded that self-control makes a significant contribution to smartphone addiction. This study also shows that self-control has a negative relationship towards smartphone addiction, where the higher the level of the students' self-control is the lower the level of their smartphone addiction. On the other hand, the lower the level of their self-control is the higher the level of their smartphone addiction. Therefore, it takes a big effort and a real role from the Guidance and Counseling Service Unit (GCSU) in helping improve the students' self-control to reduce their smartphone addiction through various guidances and counseling services such as group guiding, group counseling, individual counseling, and information services.

\section{REFERENCES}

Agusta, D. (2016). Faktor-faktor resiko kecanduan menggunakan smartphone. E-Jurnal Bimbingan Dan Konseling, 3(5), 86-96.

Asih, A. T., \& Fauziah, N. (2017). Hubungan antara kontrol diri dengan kecemasan jauh dari smartphone (nomophobia) pada mahasiswa jurusan ilmu komunikasi fakultas ilmu sosial dan politik Universitas Diponegoro Semarang. Jurnal Empati, 6(2), 15-20.

Averill, J. R. (1973). Personal control over aversive stimuli and its relationship to stress. Psychological Bulletin, 80(4), 286.

Bian, M., \& Leung, L. (2014). Linking loneliness, shyness, smartphone addiction and patterns of smartphoneuse to capital. Social Science Computer Review, 33(1), 61-79.

Chapple, C. L. (2005). Self-control, peer relations, and delinquency. Justice Quarterly, 22(1), 89-106.

Chiu, S. (2014). The relationship between life stress and smartphone addiction on taiwanese university student: a meditation model of learning self efficacy and social efficacy. Computers in Human Behavior, 34(5), 49-57.

Demirci, K., Akgonul, M., \& Akpinar, A. (2015). Relationship of smartphone use severity with sleep quality, depression, and anxiety in university students. Journal of Behavioral Addictions, 4(2), 85-92.

De Vito. (1995). The interpersonal communication book (7 Edition). New York: Harper Collins College Publisher.

Dewanti, T. C., Widada \& Triyono. (2016). Hubungan keterampilan sosial dan penggunaan gadget smartphone dengan prestasi belajar siswa SMA Negeri 9 Malang. Kajian Bimbingan Dan Konseling, 1(3), 126-131.

Griffiths, M. D. (2015). Online games, addiction and overuse of the international encyclopedia of digital communication and society. Chichester: John Wiley \& Son, Inc.

Hanika, I. M. (2015). Fenomena phubbing di era milenia. Jurnal Interaksi, 4(1), 42-51.

Jiang, Z., \& Zhao, X. (2016). Self-control and problematic mobile phone use in Chinese college students: the mediating role of mobile phone use patterns. BMC Psychiatry, 16(416), 1-8.

Karuniawan, A., \& Cahyanti, I. Y. (2013). Hubungan antara academic stress dengan smartphone addiction pada mahasiswa pengguna smartphone. Jurnal Psikologi Klinis 
Dan Kesehatan Mental, 2(1), 16-21.

Khairunnisa, A. (2013). Hubungan religiusitas dan kontrol diri dengan perilaku seksual pranikah remaja di MAN 1 Samarinda. EJournal Psikologi, 1(2), 220-229.

King et al. (2014). "Nomophobia": impact of cell phone use interfering with symptoms and emotions of individuals with panic disorder compared with a control group. Clinical Practice and Epidemiology in Mental Health: CP \& EMH, 10(5), 28-35.

Kwon, et al. (2013). Development and validation of a smartphone addiction scale ( SAS). PloS One, 8(2), 1-7.

Lepp, A., Barkley, J., \& Karpinski, A. (2013). The relationship between cell phone use, academic performance anxiety, and satisfation with life in college students. Computer in Human Behavior, 10(49), 343-350.

Manap, et al. (2016). Penggunaan dan implikasi media sosial terhadap remaja generasi Z. International Conference on Social and Economic Development,(November), 6(4),1-12.

Nasution, J. A., Neviyarni, \& Alizamar. (2017). Motif siswa memiliki smartphone dan penggunaannya. Jurnal Penelitian Pendidikan Indonesia, 3(2), 15-29.

Putra, A. Y., Ifdil. \& Afdal. (2019). Deskripsi tingkat kecanduan smartphone berdasarkan minat sosial. Jurnal Aplikasi IPTEK Indonesia, 3(1), 9-16.

Putra, Y. S. (2017). Theoritical review: teori perbedaan generasi. Among Makarti, 9(18), 615.

Rachdianti, Y. (2011). Hubungan antara self-control dengan intensitas pengggunaan internet remaja. Universitas Islam Negeri Syarif Hidayatullah.

Rambe, S.A., Mudjiran \& Marjohan. (2017). Pengembangan modul layanan informasi untuk mengembangkan kontrol diri dalam penggunaan smartphone. Jurnal Konselor, 6(4), 132-137.

Sofyan, S. W. (2010). Remaja dan masalahnya. Bandung: Alfabeta.

Thalib, S. B. (2010). Psikologi pendidikan berbasis analisis empiris aplikatif. Jakarta: Erlangga.

Waizly, D. (2012). Potret pengguna internet Indonesia tahun 2012. Jakarta: Marketeers.

Wan, C. S., \& Chiou, W. (2006). Why are adolescents addicted to online gaming? an interview study in Taiwan. Cyber Psychology \& Behavior, 9(6), 762-766.

Widiana, H. S., Retnowati, S., \& Hidayat, R. (2004). Kontrol diri dan kecenderungan kecanduan internet. Indonesian Psychologycal Journal, 1(1), 6-16.

Williams, B. K., \& Sawyer, S. C. (2011). Praise from reviewers of previous editions of using information technology. New York: McGraw-Hill.

Youarti, I. E., \& Hidayah, N. (2018). Perilaku phubbing sebagai karakter remaja generasi Z. Fokus Konseling, 4(1), 143-152.

Young, K.S., \& Cristiano, N. D. (2011). Internet Addiction. New Jersey: John Wiley \& Son, Inc.

Yusnita, Y., \& Syam, H. M. (2017). Pengaruh perilaku phubbing akibat penggunaan smartphone berlebihan terhadap interaksi sosial mahasiswa. Jurnal Ilmiah Mahasiswa FISIP Unsyiah Volume, 2(3), 1-11.

Yuwanto, L. (2010). Mobile phone addict. Surabaya: Putra Media Nusantara. 